\title{
ANALISIS PENERBITAN LAPORAN SURVEYOR PADA EKSPOR KONDENSAT MT. NEW ADVANCE DI HUSKY AREA MADURA STRAIT MARINE TERMINAL
}

\author{
Nur Rohmah ${ }^{a}$, Darul Prayoga $^{b}$, Diyan Pratiwi ${ }^{c}$ \\ ${ }^{\text {a }}$ Dosen Program Studi KALK Politeknik Ilmu Pelayaran Semarang \\ ${ }^{\mathrm{b}}$ Dosen Program Studi Teknika Politeknik Ilmu Pelayaran Semarang \\ ${ }^{c}$ Taruna Program Studi KALK Politeknik Ilmu Pelayaran Semarang
}

\begin{abstract}
ABSTRAK
Perusahaan Husky-CNOOC Madura Limited (HCML) adalah wakil dari Pemerintah Republik Indonesia untuk menjalankan kegiatan eksplorasi dan eksploitasi minyak dan gas bumi termasuk kondensat di Blok Madura Strait. Kondensat akan disalurkan kepada pembeli domestik dan mancanegara. Faktor yang mempengaruhi kelancaran ekspor di HCML adalah kelengkapan dokumen-dokumen Pemberitahuan Ekspor Barang (PEB) berupa laporan surveyor (LS). Apabila LS tidak terbit maka kuota perusahaan tidak terpenuhi seperti yang telah direncanakan. Penelitian ini bertujuan untuk mengetahui alur, kendala, dan upaya yang dilakukan dalam penerbitan laporan surveyor pada ekspor kondensat MT. New Advance di Husky Area Madura Strait Marine Terminal.

Penulis menggunakan metode deskriptif kualitatif dengan menjelaskan data secara rinci berdasarkan fakta yang ada. Untuk metode pengumpulan data, penulis melakukan observasi, wawancara, dokumentasi, serta studi kepustakaan.

Untuk menerbitkan laporan surveyor terdapat beberapa tahapan yang harus dilakukan disertai kelengkapan dokumen pendukung seperti Surat Persetujuan Ekspor (SPE). Pada pelaksanaan ekspor kondensat MT. New Advance ditemukan kendala dalam penerbitan laporan surveyor dikarenakan SPE telah kadaluwarsa dan cuaca buruk di Madura Strait Marine Terminal. Upaya yang dilakukan untuk mengatasi hal tersebut dengan melakukan pertemuan dengan pihakpihak terkait seperti INSW (Indonesia National Single Window), Kemendag, SKK Migas, dan Bea Cukai Pusat, pemeriksaan dokumen SPE secara berkala serta menjalin komunikasi yang baik antar pihak.
\end{abstract}

\section{Kata kunci: Laporan Surveyor, Ekspor, Kapal}

\section{PENDAHULUAN}

Pelabuhan adalah tempat yang terdiri dari daratan dan perairan di sekitarnya dengan batas-batas tertentu sebagai tempat kegiatan pemerintahan dan kegiatan ekonomi yang dipergunakan sebagai tempat kapal bersandar, berlabuh, naik-turun penumpang dan atau bongkar muat barang yang dilengkapi dengan fasilitas keselamatan pelayaran. Pelabuhan juga merupakan pintu suatu negara bagi keluarmasuknya arus barang ekspor impor serta arus dokumen komoditas yang melindungi barang ekspor impor tersebut. Bagi Indonesia, ekspor barang maupun jasa menjadi salah satu sumber devisa andalan guna mengisi cadangan devisa negara. Kelancaran proses ekspor suatu barang menentukan seberapa besar keuntungan yang akan diterima. Untuk mendukung hal tersebut diperlukan transportasi yang efektif dan efisien.

Transportasi laut memiliki peran yang sangat penting bagi negara kepulauan seperti Indonesia yang memiliki lebih dari 17.000 
pulau dan disatukan oleh lautan yang luas sehingga transportasi laut menjadi urat nadi bagi perekonomian bangsa ini. Jika transportasi laut terganggu, maka perekonomian nasional juga akan ikut terganggu. Sektor transportasi laut juga berperan dalam merangsang pertumbuhan ekonomi daerah-daerah tertingal (transport promote the trade) dan sebagai sarana penunjang perekonomian bagi daerahdaerah yang telah berkembang (transport follow the trade). Dengan kata lain transportasi laut berperan dalam menggerakkan dinamika pembangunan melalui mobilitas manusia, barang dan jasa serta mendukung pola distribusi nasional. Dapat disimpulkan bahwa sektor transportasi (khususnya transportasi laut bagi negara kepulauan seperti Indonesia) adalah merupakan fundamen (dasar) dari seluruh kehidupan ekonomi dan kualitas hidup bangsa. Armada kapal menjadi sangat vital sebagai urat nadi pendistribusian minyak dan gas di Indonesia. Pengiriman minyak dan gas untuk memenuhi kebutuhan pasokan dalam negeri serta luar negeri dengan menggunakan kapal laut akan lebih efisien dibandingkan dengan moda transportasi lain seperti darat maupun udara. Hal ini dikarenakan volume barang yang diangkut akan lebih besar, biaya yang dikeluarkan lebih sedikit, penanganan muatan lebih terkendali, serta jangkauan wilayahnya mampu melintasi pulau, negara bahkan benua.

Pemerintah menargetkan rata-rata produksi minyak nasional mencapai 800 ribu barel per hari di tahun 2018 (APBN 2018). Perusahaan Husky-CNOOC Madura Limited (HCML) adalah wakil dari Pemerintah Republik Indonesia untuk menjalankan kegiatan eksplorasi dan eksploitasi minyak dan gas bumi termasuk kondensat dan sulfur cair di Blok Madura Strait. Operator HCML sudah mempunyai langkah nyata untuk mendorong produksi gas bumi dari lapangan tersebut. Produksi gas bumi lapangan ini sekitar 120 juta standar kaki kubik per hari selama kurang lebih 11 tahun. Sebagai salah satu hasil produksi gas bumi, kondensat akan disalurkan kepada pembeli domestik dan mancanegara, yaitu PT. Petrokimia Gresik , PT. PLN, PT. Pertamina dan China Offshore Oil International. Distribusi kondensat sebagian menggunakan kapal milik dan kapal charter PT. Pertamina yang dalam hal ini ditangani oleh PT. Pertamina Trans Kontinental (PTK) yang bertindak sebagai agen customs clearance.

Salah satu faktor yang mempengaruhi kelancaran ekspor di HCML adalah kelengkapan dokumen-dokumen ekspor seperti Pemberitahuan Ekspor Barang (PEB). Pemberitahuan Ekspor Barang (PEB) ialah surat yang diberikan oleh pihak Bea Cukai tentang persetujuan ekspor barang ke luar negeri. Sebelum membuat PEB, PTK sebagai agen customs clearance terlebih dahulu mengajukan permohonan muat barang ekspor di luar kawasan pabean atau dengan nama fiat muat. Data yang diperlukan untuk pembuatan PEB pembuka adalah Laporan Surveyor (LS), Performa Invoice, Surat Keterangan Asal Barang (SKAB), dan lain sebagainya. Laporan Surveyor (LS) merupakan dokumen hasil verifikasi atau penelusuran teknis sebagai dokumen pelengkap yang diwajibkan dalam penyampaian pemberitahuan ekspor barang kepada kantor pabean. Salah satu dokumen yang diperlukan untuk menerbitkan LS adalah Surat Persetujuan Ekspor (SPE).

Pernah terjadi LS tidak terbit dikarenakan SPE yang sudah melewati batas waktu yang ditetapkan. Apabila LS tidak terbit maka operasional kapal akan terganggu karena kuota perusahaan tidak terpenuhi seperti yang telah direncanakan. Selain itu pengurusan PEB akan tertunda dan menjadi salah satu faktor yang dapat menghambat kelancaran keberangkatan kapal. Kelengkapan dokumen pendukung PEB berupa LS tidak bisa diabaikan begitu saja. Oleh karena itu penulis tertarik untuk mengangkat masalah tersebut yang dituangkan dalam bentuk penelitian dengan judul Analisis Penerbitan Laporan Surveyor pada Ekspor Kondensat MT. New Advance Guna Mempercepat Proses Keberangkatan Kapal Di Husky Area Madura Strait Marine Terminal.

Rumusan masalah dalam penelitian ini adalah:

1. Bagaimana alur penerbitan laporan surveyor pada ekspor kondensat MT. New Advance 
di Husky Area Madura Strait Marine Terminal?

2. Apa saja kendala penerbitan laporan surveyor pada ekspor kondensat MT. New Advance di Husky Area Madura Strait Marine Terminal?

3. Bagaimana cara mengatasi kendala penerbitan laporan surveyor pada ekspor kondensat MT. New Advance di Husky Area Madura Strait Marine Terminal?

\section{KAJIAN PUSTAKA}

A. Tinjauan Pustaka

1. Analisis

Menurut Kamus Besar Bahasa Indonesia KBBI, pengertian analisis adalah penyelidikan terhadap suatu peristiwa (karangan, perbuatan, dan sebagainya) untuk mengetahui keadaan yang sebenarnya (sebab-musabab, duduk perkaranya dan sebagainya). Menurut Satori dan Komariyah (2014:200), pengertian analisis adalah suatu usaha untuk mengurai suatu masalah atau fokus kajian menjadi bagian-bagian (decomposition) sehingga susunan atau tatanan bentuk sesuatu yang diurai itu tampak dengan jelas dan karenanya bisa secara lebih terang ditangkap maknanya atau lebih jernih dimengerti duduk perkaranya.

Menurut Kamus Pusat Pembinaan dan Pengembangan Bahasa, analisis diartikan sebagai penyelidikan terhadap suatu peristiwa (karangan, atau perbuatan) untuk mengetahui keadaan yang sebenarnya (sebab musabab, duduk perkaranya). Dapat disimpulkan bahwa analisis merupakan penguraian suatu pokok secara sistematis dalam menentukan bagian, hubungan antar bagian serta hubungannya secara menyeluruh untuk memperoleh pengertian dan pemahaman yang tepat.

2. Laporan Surveyor

Laporan merupakan suatu bentuk pertanggungjawaban atas suatu tindakan atau kegiatan yang dilakukan. Menurut Gorys Keraf (2015:284), laporan adalah suatu cara komunikasi ketika penulis menyampaikan informasi kepada seseorang atau suatu badan karena tanggung jawab yang dibebankan kepadanya. Laporan adalah setiap tulisan yang berisikan hasil pengolahan data dan informasi. Laporan berisi informasi yang didukung oleh data yang lengkap sesuai dengan fakta yang ditemukan. Berdasarkan pendapat tersebut, dapat disimpulkan bahwa laporan adalah suatu bentuk penyampaian informasi yang didukung oleh data yang lengkap sesuai dengan fakta sehingga informasi yang diberikan dapat dipercaya serta mudah dipahami.

Menurut Peraturan Menteri Perdagangan Republik Indonesia Nomor 32 tahun 2018 Pasal 1, yang dimaksud dengan surveyor adalah perusahaan survei yang mendapat otorisasi untuk melakukan verifikasi atau penelusuran teknis atas ekspor barang contoh produk industri pertambangan. Surveyor adalah seseorang yang melakukan pemeriksaan atau mengawasi dan mengamati suatu pekerjaan lainnya. Kompetensi surveyor adalah kemampuan minimal yang wajib dimiliki surveyor agar dapat bekerja dengan baik dan profesional, meliputi pengetahuan akademik, ketrampilan teknis dan karakternya. Ketiga komponen itu saling mendukung dalam diri surveyor dalam menghadapi pekerjaan yang berat di lapangan. Layanan yang diberikan surveyor antara lain pemeriksaan teknis, survei, pengkajian, penilaian pengawasan, auditing serta konsultansi di berbagai bidang. Salah satunya di bidang produksi dan eksplorasi migas, yakni layanan jasa dalam memberikan dukungan inspeksi, survei, konsultansi dan monitoring terhadap setiap mata rantai dari reservoir sampai kilang minyak dan gas bumi.

Laporan Surveyor (LS) digunakan sebagai dokumen pelengkap pabean yang diwajibkan dalam penyampaian pemberitahuan pabean ekspor barang kepada kantor pabean dan diterbitkan paling lambat 1 (satu) hari setelah dilakukan pemeriksaan muat barang. LS yang diterbitkan oleh surveyor hanya dapat dipergunakan untuk 1 (satu) kali pengapalan 
untuk pendaftaran 1 (satu) nomor Pemberitahuan Ekspor Barang (PEB). Disamping itu, LS harus memuat pernyataan kebenaran atas hasil verifikasi atau penelusuran teknis dan menjadi tanggung jawab penuh surveyor. LS sebagai hasil pemeriksaan barang ekspor yang dilakukan surveyor.

3. Ekspor

Menurut Peraturan Menteri

Perdagangan Republik Indonesia Nomor 32 Tahun 2018 Pasal 1, yang dimaksud dengan ekspor adalah kegiatan mengeluarkan barang dari daerah pabean. Barang yang telah dimuat di sarana pengangkut dan dikeluarkan dari daerah pabean dianggap telah diekspor dan diperlakukan sebagai barang ekspor (Undang-Undang Nomor 17 Tahun 2006 Pasal 2 Ayat 2). Menurut Undang-Undang Nomor 2 Tahun 2009 tentang Lembaga Pembiayaan Ekspor Indonesia Pasal 1 Ayat 4 dan Ayat 5, pengertian ekspor adalah perdagangan dengan cara mengeluarkan barang dari dalam ke luar wilayah pabean Indonesia dengan memenuhi ketentuan yang berlaku.

Ekspor adalah perbuatan mengirimkan barang ke luar Indonesia (Adrian Sutedi, 2014:7). Departemen Perdagangan dalam Kebijakan Umum Perdagangan Internasional Departemen Perindustrian dan Perdagangan, mendefinisikan bahwa ekspor adalah kegiatan mengeluarkan barang dari daerah pabean. Ekspor adalah upaya mengeluarkan barang-barang dari peredaran dalam masyarakat dan mengirimkan ke luar negeri sesuai dengan ketentuan pemerintah dan mengharapkan pembayaran dalam bentuk valuta asing (Amir M.S, 2004:100). Marolop Tandjung (2011) dalam buku Aspek dan Prosedur Ekspor Impor, mendefinisikan bahwa ekspor adalah pengeluaran barang dari daerah pabean Indonesia untuk dikirimkan ke luar negeri dengan mengikuti ketentuan yang berlaku terutama mengenai peraturan kepabeanan dan dilakukan oleh seorang eksportir atau yang mendapat izin khusus dari Direktorat
Jenderal Perdagangan Luar Negeri Departemen Perdagangan.

4. Kondensat

Kondensat merupakan Natural Gas Liquid dengan tekanan uap rendah dibandingkan dengan bensin alami, hidrokarbon ringan dan bahan bakar cair. Kondensat memiliki karakter serupa dengan minyak mentah dan digunakan sebagai bahan baku untuk penyulingan minyak dan industri petrokimia lainnya. Ada banyak sumber kondensat, dan masing-masing memiliki komposisi unik tersendiri. Secara umum, kondensat memiliki Specific Gravity berkisar antara $0,5-0,8$.

Menurut Pedoman Tata Kerja Satuan Kerja Khusus pelaksana kegiatan usaha hulu minyak dan gas bumi (SKK Migas) Nomor PTK-065/SKKMA0000/2017/S0,

pengertian kondensat adalah hidrokarbon berbentuk cair yang diperoleh dari gas alam melalui proses kondensasi atau ekstraksi. Menurut Kamus Besar Bahasa Indonesia KBBI, pengertian kondensat adalah hasil penyulingan berupa cairan maupun gas bumi berupa cairan yang didapat dari gas alam. Menurut Agnas Setiawan (2018:80), pengertian kondensat adalah hasil kegiatan eksploitasi kilang minyak berupa produk campuran dari suatu cairan hidrokarbon yang berupa komponen gas yang berasal dari gas alam mentah. Menurut H.M. Iwan Gayo (2008:241) mengatakan bahwa kondensat atau bensin alam merupakan heksan dengan tekanan uap yang relatif rendah. 


\section{B. Kerangka Pikir}

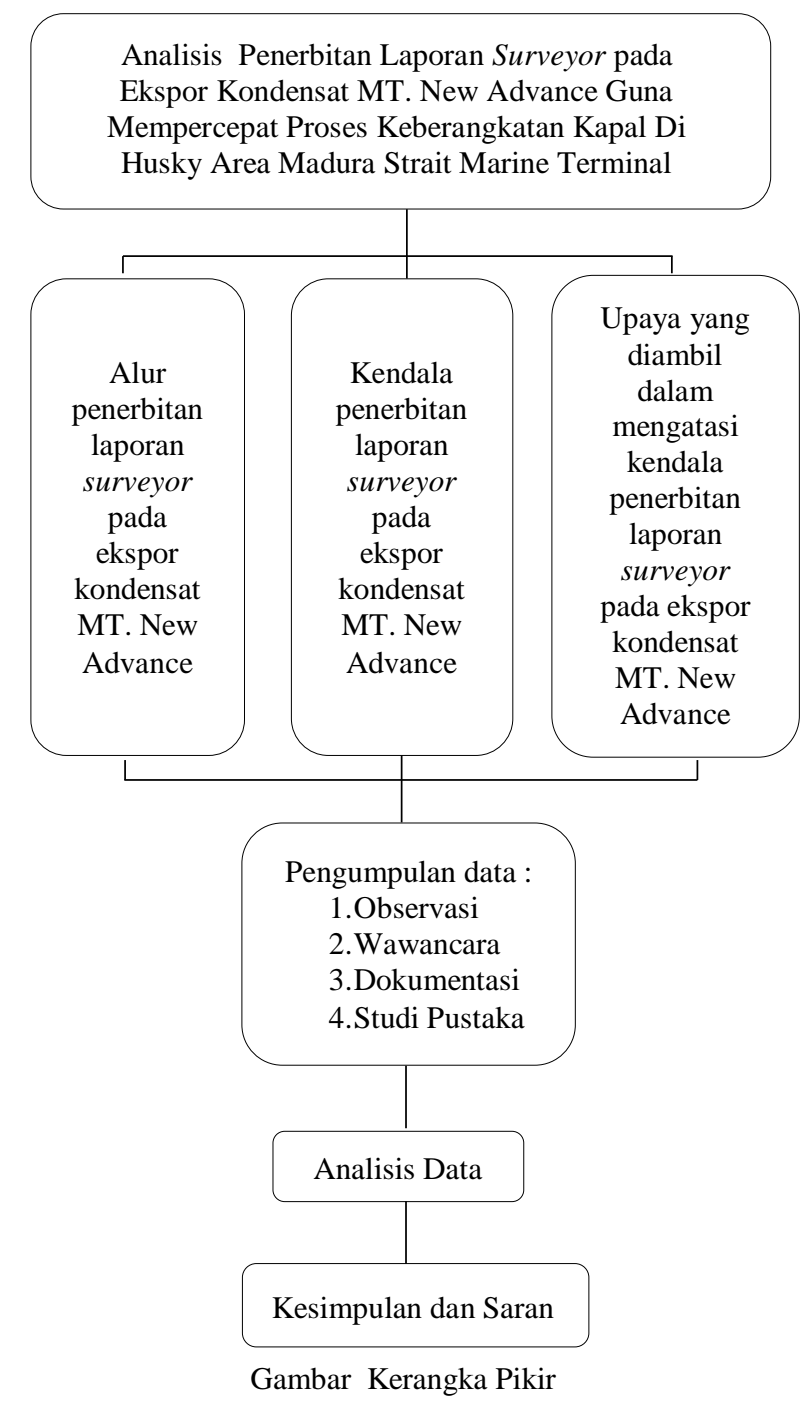

\section{METODE PENELITIAN}

Penelitian ini dilakukan selama 11 bulan ketika melaksanakan Praktek Darat (PRADA) di PT. Pertamina Trans Kontinental (PTK) Cabang Surabaya yang beralamatkan di Jalan Perak Timur 28, Pabean Cantikan, Surabaya, Jawa Timur.

Metode adalah bagian dari metodologi baik berupa teknik, prosedur, dan berbagai macam alat dengan tahap-tahap tertentu dalam suatu penelitian. Metode penelitian merupakan usaha untuk menemukan, mengembangkan, dan menguji kebenaran ilmu pengetahuan secara ilmiah. Menurut Kris H. Timotius (2017:4), metode penelitian adalah pendekatan sistematis untuk keseluruhan kegiatan penelitian. Dari uraian tersebut dapat diketahui bahwa peran penting metodologi penelitian yaitu untuk mengetahui proses dan tahapan yang digunakan untuk menjelaskan dan menguraikan fenomena atau kejadian yang terjadi pada suatu penelitian.

Metode penelitian yang digunakan dalam skripsi ini adalah metode penelitian deskriptif. Metode ini menggambarkan dan menjelaskan data secara rinci berdasarkan fakta yang ada. Penelitian deskriptif adalah penelitian yang bermaksud untuk membuat deskripsi mengenai peristiwa disertai dengan penggambaran situasi-situasi berdasarkan runtutan atau kronologi kejadian. Metode deskriptif adalah metode yang digunakan untuk menganalisis data dengan cara mendeskripsikan atau menggambarkan data yang telah terkumpul sebagaimana adanya tanpa bermaksud membuat kesimpulan yang berlaku secara umum atau generalisasi. Data-data yang digunakan dalam metode ini dapat berupa naskah wawancara, catatan di lapangan, foto, video, dokumen pribadi, memo, dan dokumen resmi yang lainnya.

Penelitian ini menggunakan berbagai macam data yang bersifat kualitatif, data tersebut bersumber dari data primer yang diperoleh selama pelaksanaan praktek darat serta ditunjang oleh data sekunder yang diperoleh dari studi pustaka. Data primer dalam penelitian ini merupakan data dari hasil observasi yang berhubungan langsung dengan objek yang diteliti selama pengamatan lapangan atau kegiatan operasional di PT. Pertamina Trans Kontinental Cabang Surabaya. Tujuannya untuk mendapatkan data yang konkret dengan melakukan tanya jawab atau wawancara dengan responden atau beberapa narasumber dari pihak terkait dalam kegiatan ekspor kondensat menggunakan metode wawancara (interview). Wawancara dilakukan kepada staf agen customs clearance dari PT. Pertamina Trans Kontinental Cabang Surabaya sebagai pihak yang mengurus hal-hal yang berkenaan dengan proses ekspor kondensat dan clearance kapal serta staf dari PT. Sucofindo sebagai pihak yang mengawasi dan membuat laporan tentang proses lifting kondensat MT. New Advance di Husky Area Madura Strait Marine Terminal. Data sekunder 
adalah data yang telah dikumpulkan pihak lain. Data tersebut bersumber dari buku-buku, literatur, jurnal, maupun referensi lainnya yang memiliki keterkaitan dengan penelitian ini sehingga dapat memberikan gambaran secara utuh, lengkap, dan menyeluruh. Penulis memperoleh data-data sekunder tersebut dari dokumen-dokumen yang dimiliki PT. Pertamina Trans Kontinental Cabang Surabaya dan referensi jurnal serta buku-buku yang berkaitan dengan proses ekspor minyak bumi maupun kondensat.

Metode pengumpulan data yang digunakan adalah sebagai berikut:

A. Metode Pengamatan (observasi)

Observasi adalah suatu penelitian secara sistematis menggunakan kemampuan indera manusia. Metode ini memungkinkan penulis melihat dan mengamati sendiri secara langsung, kemudian mencatat perilaku dan kejadian berdasarkan fakta yang sebenarnya. Metode pengamatan memungkinkan penulis untuk terjun langsung ke lapangan. Hal ini memberikan akses agar dapat mendeteksi adanya gejala yang menyimpang dan kemudian dicatat sesuai dengan kronologi peristiwa. Data yang diperoleh dengan melakukan observasi berupa gambaran tentang sikap, kelakuan, perilaku, tindakan, dan keseluruhan interaksi antar manusia. Data observasi juga dapat berupa interaksi dalam suatu organisasi atau pengalaman para anggota dalam berorganisasi.

B. Metode Wawancara (interview)

Wawancara adalah sebuah proses memperoleh keterangan untuk tujuan penelitian dengan cara tanya jawab sambil bertatap muka antara pewawancara dengan responden atau orang yang diwawancarai, dengan atau tanpa menggunakan pedoman wawancara. Wawancara dalam penelitian ini dilakukan melalui proses tanya jawab secara lisan yang berlangsung satu arah, artinya pertanyaan berasal dari pewawancara yang ditujukan pada responden. Metode wawancara bertujuan untuk menciptakan percakapan antara kedua belah pihak agar pihak pewawancara dapat mengambil intisari atas jawaban dari pertanyaan-pertanyaan tersebut. Penulis memperoleh data dari hasil wawancara dengan mengajukan pertanyaan kepada staf agen customs clearance PT. Pertamina Trans Kontinental Cabang Surabaya dan staf dari PT. Sucofindo selaku pihak-pihak yang terkait dalam penerbitan laporan surveyor pada ekspor kondensat MT. New Advance di Husky Area Madura Strait Marine Terminal.

\section{Metode Dokumentasi}

Dokumentasi adalah salah satu metode pengumpulan data kualitatif dengan melihat atau menganalisis dokumen-dokumen yang dibuat oleh subjek sendiri atau oleh orang lain tentang subjek. Bersumber dari informasi yang berasal dari catatan penting baik dari lembaga atau organisasi maupun dari perorangan. Dokumentasi penelitian ini merupakan dokumen resmi dari pihak-pihak terkait seperti Dirjen Perdagangan, HCML, dan Bea Cukai untuk memperkuat hasil penelitian. Dokumen digunakan dalam penelitian sebagai sumber data karena dimanfaatkan untuk menguji, menafsirkan, bahkan untuk meramalkan dokumen pribadi dan dokumen resmi.

D. Metode Studi Kepustakaan (literature)

Studi pustaka dimaksudkan sebagai langkah awal untuk menyiapkan kerangka penelitian guna memperoleh informasi penelitian sejenis, memperdalam kajian teoritis, dan memperdalam metodologi dengan memanfaatkan sumber perpustakaan untuk memperoleh data penelitian. Teknik studi pustaka adalah teknik pengumpulan data dengan mengadakan proses pengkajian dari beberapa buku untuk dijadikan panduan dalam mendukung penyusunan skripsi.

Teknik analisis data merupakan cara menganalisis data penelitian dengan menggunakan suatu metode atau cara untuk mengolah sebuah data menjadi informasi sehingga data tersebut menjadi mudah untuk dipahami dan berfungsi untuk menyimpulkan hasil penelitian. Analisis data yang digunakan terdiri dari tiga alur kegiatan yang terjadi 
secara bersamaan yaitu reduksi data, penyajian data kemudian penarikan kesimpulan.

1. Reduksi data

Reduksi data dapat didefinisikan sebagai proses pemilihan, pemusatan perhatian pada penyerderhanaan, pengabstrakan dan transformasi data kasar yang muncul dari catatan tertulis di lapangan. Prosesnya dimulai dengan melakukan wawancara mendalam dengan informan, yaitu orang yang benar-benar memahami dan mengetahui obyek penelitian. Setelah melakukan wawancara, analisis data dimulai dengan membuat transkrip hasil wawancara kemudian menuliskan kata-kata sesuai hasil wawancara tersebut. Langkah selanjutnya penulis membaca kembali dengan cermat untuk melakukan reduksi data dengan cara mencatat informasi-informasi yang bermanfaat sesuai dengan konteks penelitian yang relevan atau mengabaikan kata-kata yang tidak perlu, sehingga diperoleh inti kalimat dari wawancara yang telah dilakukan.

2. Penyajian data

Penyajian data merupakan data yang terkumpul dengan baik kemudian digunakan untuk keperluan informasi, laporan atau analisis. Data tersebut diatur, disusun dan disajikan dalam bentuk yang jelas, rapi, serta komunikatif dengan cara menampilkan atau menyajikan data yang lebih menarik bagi publik. Penyajian data merupakan kumpulan informasi tersusun yang memberikan kemungkinan adanya penarikan kesimpulan dan pengambilan tindakan serta disajikan dalam bentuk teks naratif.

3. Penarikan Kesimpulan

Tahap ini merupakan kegiatan penarikan kesimpulan dari semua data yang telah diperoleh sebagai hasil dari penelitian. Dapat dikatakan sebagai kegiatan interpretasi dengan menemukan makna data yang disajikan. Penarikan kesimpulan atau verifikasi adalah usaha untuk mencari atau memahami makna/arti, keteraturan, polapola, penjelasan, alur sebab akibat atau proposisi. Verifikasi merupakan tinjauan ulang pada catatan-catatan lapangan atau temuan dalam seperangkat data yang lain. Kesimpulan akhir yang diambil perlu diverifikasi agar dapat dipertanggungjawabkan.

\section{DISKUSI}

A. Bagaimana alur penerbitan laporan surveyor pada ekspor kondensat MT. New Advance guna mempercepat proses keberangkatan kapal di Husky Area Madura Strait Marine Terminal ?

Berdasarkan wawancara yang dilakukan peneliti dengan salah satu surveyor yaitu Bapak Rais dari PT Sucofindo bahwa dalam alur proses penerbitan laporan surveyor melibatkan pihak-pihak antara lain:

1. KKKS (Kontraktor Kontrak Kerja Sama) KKKS (Kontraktor Kontrak Kerja Sama) adalah pihak yang memiliki kontrak kerja sama dengan Pemerintah RI (SKK Migas), yaitu Badan Usaha Tetap atau Perusahaan Pemegang Hak Pengelolaan dalam suatu blok atau wilayah kerja yang memiliki hak untuk melakukan kegiatan eksplorasi, eksploitasi minyak dan gas bumi di Indonesia, contohnya Husky CNOOC Madura Limited (HCML). Kontrak Kerja Sama adalah Kontrak bagi hasil atau bentuk kontrak kerja sama lain dalam kegiatan eksplorasi dan eksploitasi. Jangka waktu Kontrak Kerja Sama sebagaimana tercantum dalam UU No 22/2001 adalah paling lama 30 (tiga puluh) tahun dan selanjutnya kontraktor dapat mengajukan perpanjangan lagi paling lama 20 (dua puluh) tahun. Kontrak Kerja Sama terdiri dari jangka waktu eksplorasi dan jangka waktu eksploitasi. Jangka waktu eksplorasi dilaksanakan selama 6 tahun dan dapat diperpanjang hanya 1 kali periode paling lama 4 tahun.

2. Eksportir

Eksportir adalah badan usaha, baik berbentuk badan hukum maupun tidak, termasuk perseorangan yang melakukan 
kegiatan ekspor. Eksportir wajib memberitahukan barang yang akan diekspor ke Kantor Bea dan Cukai tempat pemuatan dengan menggunakan PEB. Dalam proses ekspor kondensat MT. New Advance yang bertindak sebagai eksportir adalah Husky CNOOC Madura Limited (HCML).

3. Disperindag

Dinas Perindustrian dan Perdagangan atau yang lebih dikenal Disperindag adalah suatu instansi pemerintah daerah yang berada dibawah Kementerian Perdagangan Republik Indonesia terkait bidang perindustrian dan perdagangan yang ada di tingkat daerah atau provinsi. Pihak Disperindag bertugas untuk:

a. Perumusan kebijakan teknis di bidang perindustrian dan perdagangan.

b. Penyelenggaraan urusan pemerintahan dan pelayanan umum di bidang peridustrian dan perdagangan.

c. Penyelenggaraan urusan administrasi kesekretariatan.

d. Penyelenggaraan urusan di bidang perindustrian.

e. Penyelenggaraan urusan di bidang fasilitas dan pengembangan industri kecil menengah.

f. Penyelenggaraan urusan di bidang perdagangan luar negeri.

g. Penyelenggaraan urusan di bidang perdagangan dalam negeri

Dalam proses ekspor kondensat MT.

New Advance, pihak Disperindag berwenang dalam mengeluarkan Surat Eksportir Terdaftar (ET) yang digunakan pihak eksportir sebagai syarat maupun perijinan dalam mengekspor barang. Diketahui bahwa kuota ekspor kondensat yang diberikan kepada pihak HCML di Triwulan II adalah 525.000 barel (dokumen terlampir) berlaku sejak tanggal 11 April 2018 sampai dengan 30 Juni 2018.

4. Bea Cukai

Bea Cukai merupakan instansi penegak hukum di bidang kepabeanan dan cukai dengan jalan melaksanakan pengawasan dan pemungutan bea masuk dan pungutan negara lainnya serta memberikan pelayanan terhadap kegiatan impor dan ekspor dan melakukan koordinasi dengan instansi terkait lainnya. Bea cukai memiliki peran untuk mengawasi dan mengontrol keluar masuknya barang dari dalam maupun luar negeri di NKRI. Bea cukai memiliki beberapa fungsi, yaitu:

a. Trade facilitator, merupakan fungsi untuk memberikan fasilitas perdagangan yang bertujuan untuk menekan biaya yang tinggi sehingga akan tercipta iklim peradagangan yang lebih kondusif.

b. Industrial assistance, merupakan fungsi untuk memberikan dukungan kepada industri dalam negeri dengan tujuan untuk mencapai keunggulan kompetitif dalam pasar internasional.

c. Revenue collector, merupakan fungsi untuk mengoptimalkan penerimaan negara yang diperoleh melalui penerimaan Bea Masuk, PDRI (Pajak Dalam Rangka Impor) dan Cukai.

d. Community protector, merupakan fungsi untuk memberikan perlindungan kepada masyarakat dari barang-barang yang dilarang maupun dibatasi, yang dapat mengakibatkan gangguan terhadap kesehatan dan keamanan serta moralitas.

5. Surveyor

Surveyor adalah lembaga atau seseorang yang melakukan pemeriksaan atau mengawasi dan mengamati suatu pekerjaan lainnya. Surveyor yang dapat melakukan verifikasi ditetapkan oleh Menteri Perdagangan sesuai dengan Peraturan Menteri Perdagangan Republik Indonesia No. 56/M-DAG/PER/12/2008 dan harus memenuhi persyaratan sebagai berikut:

a. Memiliki Surat Izin Usaha Jasa Survey (SIUJS)

b. Berpengalaman sebagai surveyor minimal 5 (lima) tahun 
c. Memiliki cabang atau perwakilan dan/atau afiliasi di luar negeri dan memiliki jaringan untuk mendukung efektifitas pelayanan verifikasi

Dalam proses ekspor kondensat MT. New Advance di Madura Strait Marine Terminal yang bertindak sebagai surveyor adalah PT. Sucofindo. Sucofindo adalah bagian dari Kementerian Perdagangan yang melakukan pemeriksaan dan penilaian mutu atas barang-barang tertentu yang diimpor atau diekspor dari/ke luar negeri. Sebagai sebuah entitas bisnis, PT. Sucofindo (Persero) senantiasa berupaya meningkatkan nilai perusahaan melalui penerapan prinsip-prinsip tata kelola perusahaan yang baik (Good Corporate Governance/GCG).

6. Agen customs clearance \& in out clearance.

Agen customs clearance dan in out clearance merupakan bagian dari staf operasional PT. Pertamina Trans Kontinental Cabang Surabaya. Kedua agen tersebut memiliki tugas yang sama dalam pengurusan clearance kapal. Agen customs clearance bertugas untuk pengurusan proses penyelesaian kewajiban kepabeanan kapal berkaitan dengan dokumen-dokumen administrasi, biaya pajak, dan hal terkait lainnya yang merupakan serangkaian kegiatan yang harus dilakukan dalam rangka kegiatan ekspor maupun impor barang. Agen in out clearance bertugas untuk pengurusan in out clearance kapal yang dimulai dari pengurusan permohonan kedatangan kapal di kantor KSOP (Syahbandar), pemeriksaan dokumendokumen kapal oleh KSOP (Syahbandar), melakukan kembali permohonan keberangkatan kapal di kantor KSOP (Syahbandar), dan clearance out kapal untuk keluar dari wilayah pelabuhan.

Pihak-pihak yang telah disebutkan memiliki peran dan tanggung jawab masing-masing sesuai dengan alur penerbitan laporan surveyor yang akan disajikan dalam bagan seperti berikut:

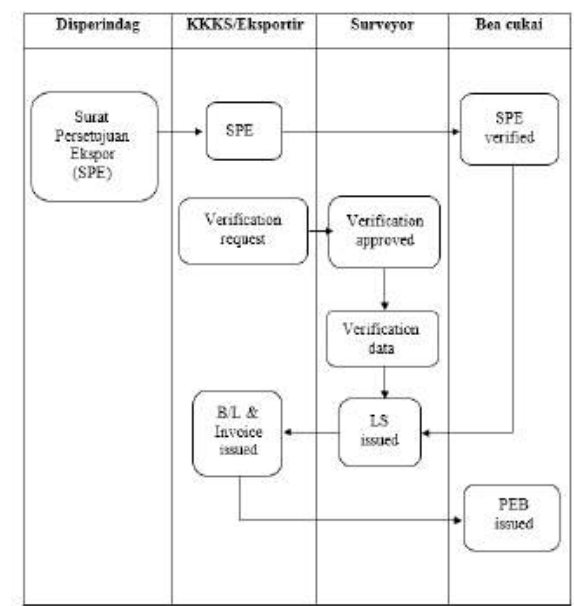

Gambar Alur Penerbitan Laporan Surveyor

Berikut penjelasan dari Gambar 4.4 :

a. KKKS atau eksportir mengajukan SPE (Surat Persetujuan Ekspor) yang dikeluarkan oleh Direktorat Jenderal Perdagangan Luar Negeri dan memuat tentang jumlah kuota ekspor yang diizinkan dalam periode tertentu ke Bea Cukai untuk mendapatkan persetujuan.

b. KKKS atau eksportir mengajukan verification request (permintaan verifikasi) ke surveyor yang ditunjuk dan sudah memiliki lisensi dari Dinas Perindustrian dan Perdagangan dalam hal ini PT Sucofindo.

c. Surveyor yang ditunjuk melakukan verifikasi data di lapangan untuk memastikan jumlah muatan yang diekspor sesuai dengan jumlah yang diajukan ke pihak Bea Cukai, kemudian jumlah muatan hasil perhitungan dijadikan dasar sebagai penerbitan Bill of Lading (B/L).

d. Berdasarkan jumlah muatan yang tercantum di Bill of Lading (B/L), pihak KKKS menerbitkan Invoice/Proforma Invoice dengan dasar harga yang sudah disetujui oleh pihak SKK Migas (Satuan Kerja Khusus Minyak \& Gas) dan Disperindag (Dinas Perindustrian dan 
Perdagangan), kemudian dilaporkan ke pihak Bea Cukai Kalianget.

e. Setelah Laporan Surveyor (LS) terbit dan status terkirim di INATRADE (Website Sistem Disperindag), secara otomatis sistem Bea Cukai akan merekam data tersebut dan menerbitkan PEB (Persetujuan Ekspor Barang).

f. Pindaian (scan) dokumen LS akan dilampirkan (upload) ke dalam sistem Disperindag setelah semua Bill of Lading (B/L) ditandatangani oleh Master kapal.

g. Hardcopy/lembar fisik LS akan dilaporkan dan diberikan kepada pihak Bea Cukai sesuai dengan areanya.

Laporan Surveyor (LS) dibutuhkan sebagai verifikasi data ekspor dari pihak independen yang sudah memiliki lisensi dan terdaftar di Kementerian Perdagangan atau Disperindag yang telah ditunjuk oleh pihak eksportir (KKKS terkait). Dokumen LS memuat keterangan-keterangan sebagai berikut:

a. Data eksportir, meliputi:

1) Nama perusahaan

2) Alamat

3) NPWP (Nomor Pokok Wajib Pajak)

b. Data importir, meliputi:

1) Nama

2) Alamat

3) SPI (Surat Persetujuan Impor)

4) API (Angka Pengenal Impor)

c. Data shipment, meliputi:

1) Jenis moda transportasi

2) Nama kapal

3) Nomor voyage

4) Pelabuhan muat

5) Pelabuhan bongkar

6) Nomor dan tanggal invoice

7) Nomor dan tanggal L/C (Letter of Credit)

8) Nomor dan tanggal B/L (Bill of Lading)

9) Tempat dan tanggal inspeksi

\section{d. Details of cargo}

1) Kode HS

2) Deskripsi cargo

3) Negara asal cargo

4) Jumlah cargo

Dalam LS dicantumkan jumlah barel yang telah diambil. Dari jumlah tersebut akan diketahui sisa kuota Husky yang harus diekspor sehingga targetnya dapat terpenuhi.

B. Apa saja kendala penerbitan laporan surveyor pada ekspor kondensat MT. New Advance guna mempercepat proses keberangkatan kapal di Husky Area Madura Strait Marine Terminal?

Ada beberapa kendala yang ditemukan dalam penerbitan laporan surveyor pada ekspor kondensat MT. New Advance yaitu :

1. Surat Persetujuan Ekspor (SPE) melebihi batas waktu yang ditentukan atau dapat dikatakan kadaluwarsa (expired) karena keterlambatan penyelesaian pemuatan yang disebabkan oleh kendala emergency shut down dan cuaca buruk. SPE memiliki batas waktu yang apabila kadaluwarsa akan menimbulkan masalah dalam pengurusan penerbitan laporan surveyor. SPE memuat kuota ekspor yang diizinkan oleh Disperindag, sedangkan laporan surveyor memuat jumlah ekspor yang direalisasikan. Apabila SPE sudah kadaluwarsa, maka akan diragukan keabsahannya. Setiap kali kegiatan ekspor dilakukan harus dicatat secara rinci dengan laporan surveyor untuk mengetahui apakah target atau kuota yang telah diberikan sudah tercapai atau belum. Selain itu SPE juga merupakan dokumen pendukung untuk penerbitan laporan surveyor.

2. Force Majeure

Adalah suatu kejadian yang terjadi di luar kemampuan manusia dan tidak dapat dihindarkan sehingga suatu kegiatan tidak dapat dilaksanakan sebagaimana mestinya. Yang termasuk kategori force majeure adalah peperangan, kerusuhan, revolusi, bencana alam, pemogokan, kebakaran, dan bencana lainnya yang 
harus dinyatakan oleh pejabat/instansi yang berwenang. Force majeure yang terjadi saat proses loading kondensat MT. New Advance di Madura Strait Marine Terminal adalah cuaca buruk dengan kecepatan angin lebih dari 25 knot dan tinggi gelombang mencapai 2,5 meter. Keadaan angin dan tinggi gelombang yang terjadi masuk dalam kategori bahaya sehingga proses loading harus dihentikan sementara menunggu instruksi selanjutnya sampai keadaan sekitar dinyatakan aman oleh pihak KUPP Branta.

C. Bagaimana cara mengatasi kendala penerbitan laporan surveyor pada ekspor kondensat MT. New Advance guna mempercepat proses keberangkatan kapal di Husky Area Madura Strait Marine Terminal?

Ada 3 hal yang bisa dilakukan dalam mengatasi kendala tersebut yaitu:

1. Melakukan pertemuan dengan pihak terkait

Langkah nyata yang diambil oleh pihak eksportir (HCML) adalah melakukan pertemuan dengan pihak terkait seperti Biro Hukum ESDM, Ditjen Migas, Ditjen Perdagangan Luar Negeri, dan PT Sucofindo dijembatani oleh Dirjen Bea Cukai Pusat dalam rangka penerbitan surat keterangan/dukungan kepada Ditjen Perdagangan Luar Negeri terkait dengan penerbitan Laporan Surveyor.

2. Memeriksa dan selalu mengecek masa berlaku SPE

Pihak HCML selaku eksportir harus mengetahui dan senantiasa memeriksa masa berlaku SPE agar setiap kegiatan ekspor dapat berjalan dengan lancar dan mampu memenuhi target yang telah ditentukan sebelumnya. Selain itu pihak HCML juga harus memperhatikan ketentuan-ketentuan yang dipaparkan dalam SPE seperti :

a) Wajib memperhatikan dan mempertimbangkan kondisi pasokan dan kebutuhan di dalam negeri. Apabila kondisi pasokan dan kebutuhan di dalam negeri tidak mencukupi, maka persetujuan ekspor HCML dapat ditinjau kembali atau dibatalkan.

b) Wajib melakukan verifikasi atau penelusuran teknis di pelabuhan muat barang oleh Surveyor yang telah ditetapkan Menteri Perdagangan.

c) Wajib menunjukkan Surat Persetujuan Ekspor Minyak Bumi dan Gas Bumi kepada petugas Bea dan Cukai setempat untuk setiap kegiatan ekspor, guna pengisian Kartu Kendali Realisasi Ekspor yang mencakup verifikasi jumlah dan jenis barang yang diekspor.

d) Wajib menyampaikan laporan atas pelaksanaan ekspor Minyak Bumi dan Gas Bumi melalui http://inatrade.kemendag.go.id , setiap bulan paling lambat tanggal 15 (lima belas) bulan berikutnya terhitung sejak diterbitkannya Persetujuan Ekspor Minyak Bumi dan Gas Bumi kepada Direktur Jenderal Perdagangan Luar Negeri.

e) Persetujuan Ekspor Minyak Bumi dan Gas Bumi ini dicabut, apabila tidak menyampaikan laporan pelaksanaan ekspor, menyampaikan data dan/atau informasi yang tidak benar untuk mendapatkan Persetujuan Ekspor Minyak Bumi dan Gas Bumi, mengubah data dan/atau informasi yang tercantum dalam Persetujuan Ekspor Minyak Bumi dan Gas Bumi, mengekspor Minyak Bumi dan Gas Bumi yang jenisnya tidak sesuai dan/atau jumlahnya melebihi yang tercantum dalam Persetujuan Ekspor Minyak Bumi dan Gas Bumi dan dinyatakan bersalah berdasarkan putusan pengadilan atas tindak pidana yang berkaitan dengan penyalahgunaan Persetujuan Ekspor Minyak Bumi dan Gas Bumi.

f) HCML dapat disetujui untuk mengekspor produk Minyak Bumi dan Gas Bumi dengan uraian barang, Pos Tarif/HS, dan jumlah yang telah ditentukan. 
g) Persetujuan Ekspor Minyak Bumi dan Gas Bumi mulai berlaku sejak tanggal yang telah ditetapkan sampai dengan batas waktu pengapalan yang dibuktikan dengan diserahkannya pemberitahuan pabean sesuai dengan ketentuan kepabeanan di bidang ekspor.

h) HCML bertanggungjawab terhadap segala akibat hukum yang timbul disebabkan oleh perbuatan, tindakan, pelanggaran baik disengaja atau tidak sengaja, dan kelalaian yang tidak sesuai dengan ketentuan peraturan perundang-undangan atas ekspor Produk Ekspor Minyak Bumi dan Gas Bumi yang dilakukan

3. Menjalin komunikasi yang baik dengan pihak-pihak terkait

PTK sebagai agen customs clearance hendaknya memiliki komunikasi dan membina hubungan yang baik dengan pihak-pihak terkait seperti eksportir dan Bea Cukai sehingga apabila timbul permasalahan dapat segera diatasi dan semua kegiatan yang telah direncanakan dapat berjalan dengan lancar.

\section{KESIMPULAN}

Berdasarkan hasil penelitian dan pengolahan data yang telah diperoleh penulis tentang analisis penerbitan laporan surveyor pada ekspor kondensat MT. New Advance guna mempercepat proses keberangkatan kapal di Husky Area Madura Strait Marine Terminal, maka kesimpulan yang dapat diambil adalah :

1. Alur penerbitan laporan surveyor pada ekspor kondensat MT. New Advance di Husky Area Madura Strait Marine Terminal yakni sebagai berikut:

a. KKKS atau eksportir mengajukan SPE (Surat Persetujuan Ekspor) ke Bea Cukai untuk mendapatkan persetujuan.

b. KKKS atau eksportir mengajukan verification request (permintaan verifikasi) ke surveyor yang ditunjuk dan sudah memiliki lisensi dari Dinas
Perindustrian dan Perdagangan dalam hal ini PT Sucofindo.

c. Surveyor yang ditunjuk melakukan verifikasi data di lapangan untuk memastikan jumlah muatan yang diekspor sesuai dengan jumlah yang diajukan ke pihak Bea Cukai yang akan dijadikan dasar sebagai penerbitan Bill of Lading (B/L).

d. Berdasarkan jumlah muatan yang tercantum di Bill of Lading (B/L), pihak KKKS menerbitkan Invoice/Proforma Invoice), kemudian dilaporkan ke pihak Bea Cukai Kalianget.

e. Setelah Laporan Surveyor (LS) terbit dan status sent di INATRADE (Website Sistem DISPERINDAG), secara otomatis sistem Bea Cukai akan merekam data tersebut dan menerbitkan PEB (Persetujuan Ekspor Barang).

f. Pindaian (scan) dokumen LS akan dilampirkan (upload) ke dalam sistem DISPERINDAG setelah semua Bill of Lading (B/L) ditandatangani oleh Master kapal.

g. Hardcopy/lembar fisik LS akan dilaporkan dan diberikan kepada pihak Bea Cukai sesuai dengan areanya.

2. Kendala penerbitan laporan surveyor pada ekspor kondensat MT. New Advance guna mempercepat proses keberangkatan kapal di Husky Area Madura Strait Marine Terminal adalah sebagai berikut:

a. SPE (Surat Persetujuan Ekspor) yang telah melewati batas waktu atau dikatakan kadaluwarsa (expired).

b. Force Majeure berupa cuaca buruk dengan kecepatan angin lebih dari 25 knot dan tinggi gelombang mencapai 2,5 meter.

3. Upaya mengatasi kendala penerbitan laporan surveyor pada ekspor kondensat MT. New Advance guna mempercepat proses keberangkatan kapal di Husky Area Madura Strait Marine Terminal adalah sebagai berikut:

a. Pihak eksportir melakukan pertemuan dengan pihak terkait seperti INSW (Indonesia National Single Window), 
Kemendag, SKK Migas, dan Bea Cukai Pusat.

b. Pihak eksportir memeriksa dan selalu mengecek masa berlaku SPE.

\section{DAFTAR PUSTAKA}

H.M. Iwan Gayo. 2008, Buku Pintar: Seri Senior. Jakarta: Grasindo.

Keraf, Gorys. 2015, Diksi dan Gaya Bahasa. Jakarta: Gramedia Pustaka Utama.

M.S, Amir. 2004, Strategi Memasuki Pasar Ekspor. Jakarta: PPM.

Pedoman Tata Kerja Satuan Kerja Khusus Pelaksana Kegiatan Usaha Hulu Minyak dan Gas Bumi (SKK Migas) Nomor PTK065/SKKMA0000/2017/S0.

Peraturan Menteri Perdagangan Republik Indonesia Nomor 32 Tahun 2018 tentang Ketentuan Ekspor Produk Industri Pertambangan sebagai Barang Contoh Untuk Keperluan Penelitian dan Pengembangan Teknologi Pengolahan dan/atau Pemurnian.

Peraturan Menteri Perdagangan Republik Indonesia Nomor 32 tahun 2018 Pasal 1

Satori, dan Komariyah. 2014, Metode Penelitian Kualitatif. Bandung: Alfabeta.

Setiawan, Agnas. 2018, Membuka Wawasan dengan Geografi. Yogyakarta: Deepublish.

Sutedi, Adrian. 2014. Hukum Ekspor Impor. Jakarta: Raih Asa Sukses.

Tandjung, Marolop. 2011, Aspek dan Prosedur Ekspor Impor. Jakarta: Salemba Empat.

Timotius, Kris H. 2017. Pengantar Metode Penelitian. Yogyakarta: Andi.

Undang-Undang Nomor 17 Tahun 2006 Pasal 2 Ayat 2.

Undang-Undang Nomor 2 Tahun 2009 tentang Lembaga Pembiayaan Ekspor Indonesia.

Undang-Undang Nomor 2 Tahun 2009 tentang Lembaga Pembiayaan Ekspor Indonesia Pasal 1 Ayat 4 dan Ayat 5.
Undang-undang Republik Indonesia Nomor 17 Tahun 2006 tentang Perubahan atas Undang-undang Nomor 10 Tahun 1995 tentang Kepabeanan 